(C) Masson, Paris, 1979.

Annales de Parasitologie (Paris)

1979 , t. $54, \mathrm{n}^{\circ} 1$, pp. 65-68.

\title{
Helminths of birds and mammals of Israel
}

\author{
VIII. - Skrjabinocapillaria rodentium n. sp. \\ (Nematoda Capillariidae) from gerbillid and murid rodents
}

\author{
by Guta WERTHEIM * and A.-G. CHABAUD ** \\ * Laboratory of Helminthology, The Hebrew University \\ Hadassah Medical School, Jerusalem, Israel
}

** Laboratoire de Zoologie (Vers), associé au C.N.R.S., Muséum National d'Histoire Naturelle, 43, rue Cuvier, F 75231 Paris Cedex 05.

\section{Résumé.}

Helminthes d'Oiseaux et de Mammifères d'Israël. VIII. Skrjabinocapillaria rodentium n. sp. (Nematoda-Capillariidae), parasite de Rongeurs muridés et gerbillidés.

Description de Skrjabinocapillaria rodentium n.sp., parasite de l'estomac de Meriones crassus, Gerbillus pyramidum, G. gerbillus, G. dasyurus et Acomys cahirinus. Il diffère des deux autres espèces du genre, $S$. bakeri et $S$. eubursata, par sa grande taille, le grand nombre de stichocytes et une vésicule céphalique chez la femelle et non chez le mâle.

\section{Summary.}

Skrjabinocapillaria rodentium n.sp., found in the stomach of Meriones crassus, Gerbillus pyramidum, G. gerbillus, G. dasyurus and Acomys cahirinus, is described. It differs from the other two species in the genus, $S$. bakeri and $S$. eubursata, mainly in being larger, having a larger number of stichocytes and having a cephalic influation in the female and not in the male.

\section{Introduction}

Numerous capillariid nematodes were found in the stomach of gerbillid and murid rodents collected in arid regions of the Negev (Southern Israel) and in the Sinai peninsula. These nematodes, identified previously as Capillaria $s p$. (Wertheim

Accepté le 30 octobre 1978. 
and Greenberg, 1970) were found to belong in the genus Skrjabinocapillaria Skarbilovitsch, 1946, but differ from the other two species in the genus, $S$. bakeri Mueller and Van Cleave, 1932 and S. eubursata Skrabilovitsch, 1946 and are described as a new species.

The description was made from specimens fixed in alcohol-formalin-acetic acid and cleared in lactophenol. Cross sections of the worms were prepared with a razor blade. All measurements are in microns (unless otherwise indicated).

\section{Description based on 6 males and 10 females}

\section{Skrjabinocapillaria rodentium $\mathrm{n}$. $\mathrm{sp}$.}

Filiform nematodes; cuticle finely striated. Funnel shaped openings of bacillarycell ducts situated in two wide, lateral fields over the entire length (fig. 1, A). Mouth simple; cephalic and caudal extremities blund. Sexual dimorphism considerable: males slender, cylindrical; females with body markedly wider in the posterior two thirds and with a cephalic inflation.

MALE

Length : 24.3-42.4 mm (average $32.6 \mathrm{~mm}$ ) ; maximum width 90 to 108 (average 97) in second third of body. Width at anterior end 13 to 25 (average 18) (fig. 1, C). Width at level of posterior end of oesophagus 80 to 100 (average 86) (fig. 1, E). Width of caudal end 15 to 20 (average 17.4); average ratio of width at level of posterior end of oesophagus to maximum width 1: 1.1. Pharynx narrow, 6 to 8 long. Oesophagus 4.9 to 7.2 long (average $6.4 \mathrm{~mm}$ ). Ratio of length of oesophagus to length of body $1: 4.4$ to $1: 6.7$ (average 1.5). Muscular part, of oesophagus 268 to 345 long (average 308). Stichosome with 106 to 135 cells (average 118). Nerve ring 60 to 70 from anterior end. Spicular sheath aspinose 276 to 363 long (average 312) (fig. 1, G). Cloaca terminal. Males with everted spicular sheath not observed.

\section{Female}

Length 58.0 to $77.0 \mathrm{~mm}$ (average $66.5 \mathrm{~mm}$ ) ; maximum width in second third 270 to 346 (average 310); width at cephalic end 12 to 23 (average 18.4); width at level of posterior trichocytes 150 to 210 (average 18.4); width at level of posterior end of oesophagus 123 to 172 (average 178) ; width at level of vulva 145 to 198 (average 176) (fig. $1, D$ ); width at posterior end 25 to 45 (average 39). Ratio of body width at level of vulva to maximum width $1: 1.5$ to $1: 1.2$ (average $1: 1.7$ ) ; distance of cephalic inflation from anterior end 10 to 18 (average 13) ; length of cephalic inflation 62 to 134 (average 92) (fig. $1 \mathrm{~B}$ ).

Oesophagus 5.8 to $6.7 \mathrm{~mm}$ long (average $6.4 \mathrm{~mm}$ ). Ratio of length of oesophagus to body length $1: 9.3$ to $1: 11.6$ (average $1: 10.4$ ). Muscular part of oesophagus 310 to 400 long (average 354). Stichosome with 118 to 136 cells (average 127). Distance from posterior end of oesophagus to vulva 48 to 135 (average 78.3). Distance of vulva from anterior end about $6.5 \mathrm{~mm}$. Anus terminal (fig. 1, F). Uterus with numerous eggs 70 to 84 by 35 to 50 ; embryonated in utero and in vagina. Egg shell thin and smooth (fig. $1, H$ ).

TyPe HOST: Meriones crassus Sundevall. Other hosts: Acomys cahirinus Desmarest ; Gerbillus dasyurus Wagner, G. gerbillus Olivier, G. pyramidum Geoffroy. TyPe Locality: Ein Yahav (Negev). 

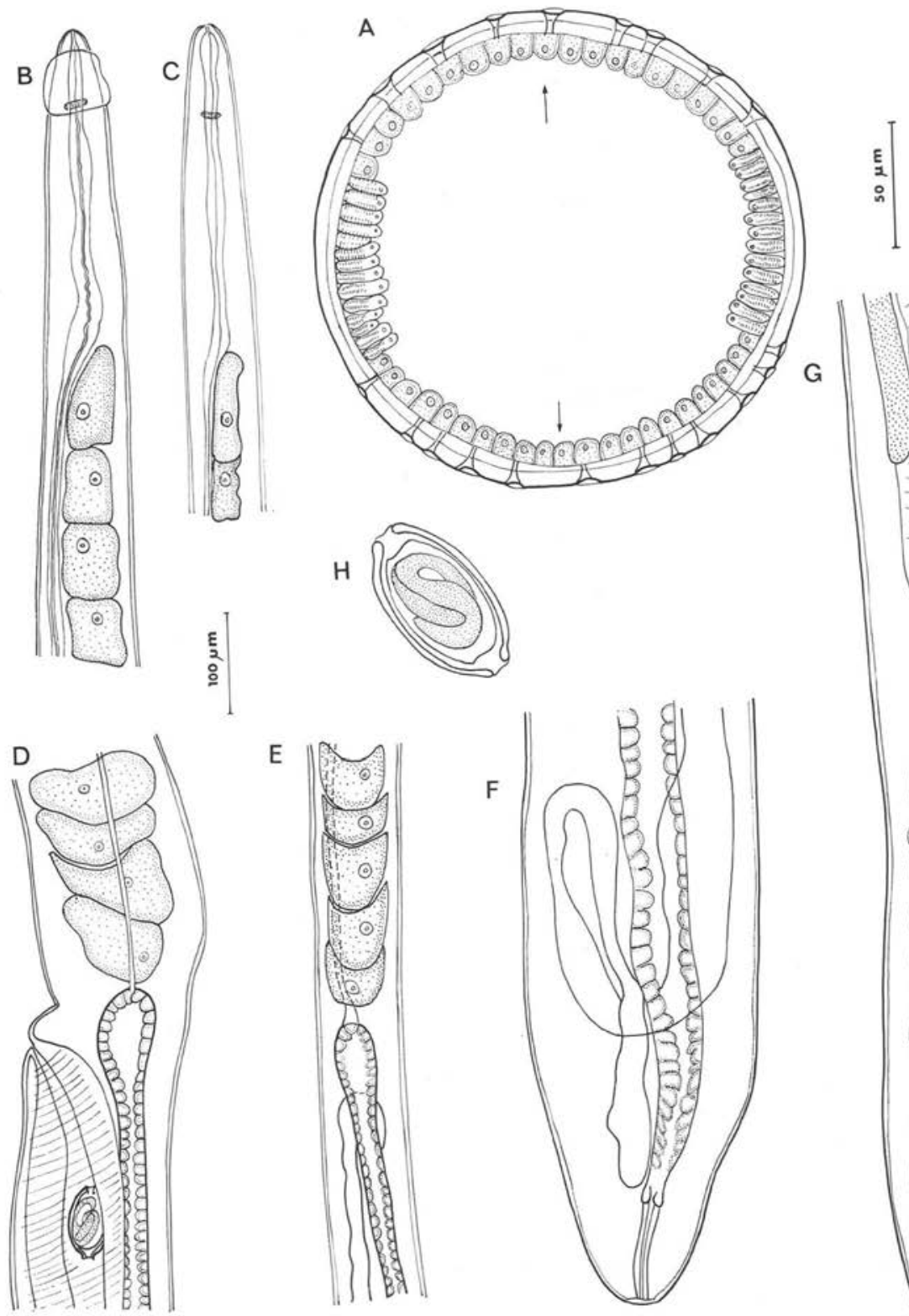

E

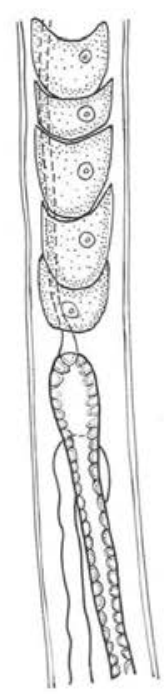

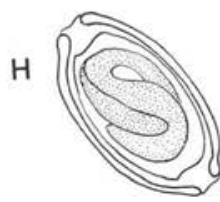

(1)<smiles>C1CC2CCCC2C1</smiles>

$\mathrm{F}$

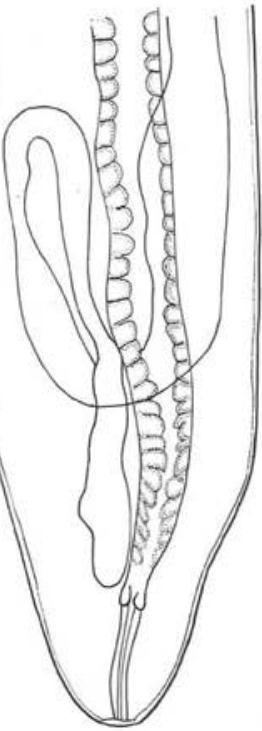

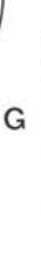

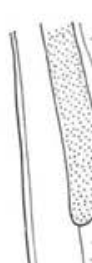

Fig. 1. - Skrjabinocapillaria rodentium n.sp. A : Female, cross section in the second third of body (semischematic). Note lateral fields of bacillary cells and ducts (arrows). B, Female, anterior end; C, Male, anterior end; D, Female, region of vulva; E, Male, posterior end of oesophagus; F, Female, posterior end; G, Male, posterior end; H, egg; G, H, scale $50 \mu \mathrm{m}$; A, B, C, D, E, F, scale $100 \mu \mathrm{m}$. 
LOCALIZATION : stomach.

Types: Male holotype, allotype and paratypes $\mathrm{N}^{\circ} 1031 \mathrm{CA}, \mathrm{N} 388$ in the collection of M.N.H.N., Paris, Laboratoire des Vers.

\section{Discussion}

The genus Skrjabinocapillaria Skarbilovitsch, 1946 is characterized by an aspinose spicular sheath and absence of a spicule. Two species were described: $S$. bakeri, found in the intestine of several fish species in the U.S.A. and $S$. eubursata, first recovered from the stomach of unidentified bats (Skarbilovitsch, 1946) in the SSSR, and later also found in Rhinolophus hipposideros Bedist, Myotis dasycneme Boie, M. mystacinus Kuhl, Plecotus auritus L., Nyctalus leisleri Kuhl, N. noctula Schreb. and Eptesicus serotinus Schreb. in the Moldavian SSR (Skvorcov, 1973).

$S$. rodentium differs from both species in its larger size, a larger number of stichocytes, a much higher ratio of the length of the œsophagus to body length (female over 1:10.4, male over $1: 5$ as compared to $1: 1.3$ in both species), a sexual dimorphism expressed in the presence of a cephalic inflation in the female only, the lack of a caudal bursa in the male (observed only in S. eubursata) and in having larger eggs.

The present state of the taxonomy of the Capillariidae on the generic level is far from presenting any natural, evolutionary trend. The sporadic distribution of the three species of Skrjabinocapillaria in different vertebrate groups (fish, bats and rodents) and over a wide geographical area (U.S.A., SSSR and Israel) does not permit to draw any conclusions as to its natural affinities.

\section{Bibliographie}

Mueller J.F., Van Cleave J. (1932): Parasites of Oneida Lake Fisches. Part II. Descriptions of new species and some general taxonomic considerations concerning the trematode family Heterophyidae. Roosevelt Wild Life Ann., 4, 79-137.

Skarbilovitch T.S. (1946): K poznaniu Gelmintofauni vukokvilich SSSR. Gelmintologicheski Sbornik dedicated to K. Y. Skrjabin on the 40th anniversary of his scientific activity. pp. 235-244. Izdatelstvo Akademi Nauk SSSR, Moskva-Leningrad.

Skvortzov B. G. (1973): Ecologo-faunicheski obsov gelmintofauni letuchei mishei moldavi. «Parasiti zivotnichi rasteni » Academia Nauk Moldavskoi SSR. Izdatelstvo, «Shtiintza » Kishiniev.

Wertheim G., Greenberg Z. (1970): Notes on helminth parasites of myomorph rodents from Southern Sinai. J. Helminthol., 44, 243-252. 